DOI: $10.14720 /$ aas.2016.107.1.04

Agrovoc descriptors: zea mays; maize; foliar application; silicon; cold stress; abiotic stress; physiological response; temperature resistance; cold tolerance; lipid peroxidation

Agris category code: F40, f60, f62

\title{
Effect of foliar-applied silicon on photochemistry, antioxidant capacity and growth in maize plants subjected to chilling stress
}

\author{
Ghader HABIBI ${ }^{1} *$
}

Received December 11, 2015; accepted February 09, 2016.

Delo je prispelo 11. decembra 2015, sprejeto 09. februarja 2016.

\begin{abstract}
Low temperature is one of the major adverse climatic factors that suppress plant growth and sustainable agricultural development. In these climate conditions, silicon $(\mathrm{Si})$ can mitigate various abiotic stresses including low temperature. In this study, the roles of foliar-applied silicon $(10 \mathrm{mM}$ potassium metasilicate) in enhancing tolerance to chilling stress were investigated in maize (Zea mays 'Fajr') plants. The low temperature stress caused significant reduction of plant growth and relative water content; however, $\mathrm{Si}$ ameliorated these effects. Si supply in maize exhibited a significantly positive effect on accumulation of free amino acids, and reduced the necrotic leaf area. The decrease in maximum quantum yield of PSII $\left(\mathrm{F}_{\mathrm{v}} / \mathrm{F}_{\mathrm{m}}\right)$ was reversible during recovery, but not in the non-Si-treated leaves. This can be explained by enhancement of protective pigments; carotenoid and anthocyanin leading to the protection of PSII from damage. Additionally, analysis of OJIP transients revealed that $\mathrm{Si}$ reduced cold damaging effect on performance index $\left(\mathrm{PI}_{a b s}\right)$ and $\mathrm{F}_{\mathrm{v}} / \mathrm{F}_{\mathrm{m}}$ through improvement of excitation energy trapping $\left(\mathrm{TR}_{0} / \mathrm{CS}\right)$ and electron transport $\left(\mathrm{ET}_{0} / \mathrm{CS}\right)$ per excited crosssection of leaf. The malondialdehyde (MDA) concentration, which was significantly increased under chilling stress, was decreased by $\mathrm{Si}$. The reduced glutathione and ascorbate concentrations were higher in Si-treated plants as compared to those without application of $\mathrm{Si}$ under chilling stress. These results indicated that $\mathrm{Si}$ could enhance the chilling stress tolerance of maize plants through improving the biomass accumulation, maintaining a high level of glutathione, ascorbic acid, protein, protective pigments, and enhancing the photochemical reactions. This study also suggests that the foliar-applied $\mathrm{Si}$ increases recovery ability from chilling injury.
\end{abstract}

Key words: chilling stress, lipid peroxidation, nonphotochemical quenching, silicon, Zea mays

\section{IZVLEČEK}

\author{
UČINEK FOLIARNEGA DODAJANJA SILICIJA NA \\ FOTOKEMIČNO IN ANTIOKSIDACIJSKO \\ UČINKOVITOST TER RAST KORUZE V RAZMERAH \\ HLADNEGA STRESA
}

\begin{abstract}
Nizka temperatura je eden izmed glavnih neugodnih klimatskih dejavnikov, ki zavira rast rastlin in trajnostni razvoj kmetijstva.V takšnih klimatskih razmerah lahko silicij oblaži abiotski stress vključno $\mathrm{z}$ učinki nizke temperature. $\mathrm{V}$ tej raziskavi je bila preučevana vloga foliarnega dodajanja Si (10 $\mathrm{mM}$ kalijevega metasilikata) pri povečevanju odpornosti koruze (Zea mays 'Fajr') na hladni stres. Stres zaradi nizkih temperature je značilno zmanjšal rast in vsebnost vode $\mathrm{v}$ rastlinah, kar je dodajanje Si oblažilo. Dodatek silicija je sprožil v koruzi značilne pozitivne učinke $\mathrm{v}$ kopičenju prostih amino kislin in $\mathrm{v}$ zmanjšanju nekrotičnosti listov. Zmanjšanje $\mathrm{v}$ fotokemični učinkovitosti PS II $\left(\mathrm{F}_{\mathrm{v}} / \mathrm{F}_{\mathrm{m}}\right)$ je bilo povratno med okrevanjem, vendar ne pri rastlinah, ki niso bile tretirane s silicijem. To bi lahko razložili s povečanjem vsebnosti zaščitnih pigmentov karotenoidov in antocianinov, kar vodi v zaščito PSII pred poškodbami. Dodatno so analize prehodne fluorescence klorofila a (OJIP) odkrile, da je dodatek Si zmanjšal učinek poškodb zaradi hlada na fotosintetski elektronski transport $\left(\mathrm{PI}_{\mathrm{abs}}\right.$ in $\left.\mathrm{F}_{\mathrm{v}} / \mathrm{F}_{\mathrm{m}}\right)$ preko boljšega prestrezanja ekscitacijske energije $\left(\mathrm{TR}_{0} / \mathrm{CS}\right)$ in boljšega elektronskega transporta $\left(\mathrm{ET}_{0} / \mathrm{CS}\right)$ na presek ekscitiranega lista. Hladni stres je povzročil poškodbe membran, kar se je odrazilo $\mathrm{v}$ povečani koncentraciji malondialdehida. $\mathrm{V}$ rastlinah tretiranih $\mathrm{s} \mathrm{Si}$ koncentracija malondialdehide ni dosegla ravni rastlin, izpostavljenih hladnem stresu. Koncentracije reduciranega glutationa in askorbata so bile večje $\mathrm{v}$ rastlinah, tretiranih $\mathrm{s} \mathrm{Si} \mathrm{v}$ razmerah hladnega stresa $\mathrm{V}$ primerjavi s tistimi, ki s silicijem niso bile tretirane. Ti rezultati nakazujejo, da bi lahko silicij povečal odpornost na hladni stres pri koruzi z izboljšanjem prirastka biomase, vzdrževanjem visoke ravni glutationa, askorbinske kisline, beljakovin, zaščitnih pigmentov in $\mathrm{v}$ povečevanju fotokemičnih reakcij. Raziskava nakazuje, da foliarno dodajanje silicija povečuje sposobnost okrevanja iz od hlada nastalih poškodb.
\end{abstract}

Ključne besede: hladni stres, peroksidacija lipidov, nefotokemična pretvorba svetlobe, silicij, Zea mays

Department of Biology, Payame Noor University (PNU), Iran; Correspondence; gader.habibi@gmail.com 


\section{INTRODUCTION}

Because of global climate change, we can expect increased damage to plants, such as increased spring frost. Cold stress includes chilling $\left(<20^{\circ} \mathrm{C}\right)$ and/or freezing $\left(<0 \quad{ }^{\circ} \mathrm{C}\right)$ temperatures, and negatively affects the growth and development of plants (Waśkiewicz et al., 2014). Exposure to cold increases the production of reactive oxygen species (ROS) (Zhang et al., 2011), resulting in cytotoxic conditions that affects plant metabolism by stimulating oxidative damage to lipid, proteins, and nucleic acid (Suzuki et al., 2012).

To alleviate the effect of cold stress, plants adapt various approaches for their survival. Proper plant nutrition is one of the strategies in mitigating the stress induced damage in plants (Habibi, 2014a). Si is the second most common element in the lithosphere after oxygen and has been proved to be beneficial for the healthy growth and development of many plant species; particularly Gramineae plants (Broadley et al., 2011). Si application to crops has been reported to enhance their tolerance of multiple stresses (Guntzer, 2011), including pests and pathogens (Dallagnol et al., 2012), salt and water stress (Liu et al., 2014). However, the effects of Si on plant resistance to cold stress and the underlying mechanisms have not been well identified (Liang et al., 2008). It has been reported that the protective role of $\mathrm{Si}$ in plants exposed to cold-stress conditions in most cases has been attributed to increase water use efficiency and antioxidant activity in winter wheat (Liang et al., 2008) and cucumber leaves (Liu et al., 2009). In previous work, we concluded that supplementation of water-deficient pistachio (Habibi and Hajiboland, 2013) and canola (Habibi, 2014b) plants with $\mathrm{Si}$ alleviates the adverse effects of drought due to its enhancement of photochemical efficiency and photosynthetic gas exchange, as well as an activation of the antioxidant defense capacity in these plants.

The maize (Zea mays) is one of the most important crops, and adaptation of this plant to early annual planting dates requires improvement of chilling tolerance (Battal et al. 2008). One of the major problems arising in some maize cultivation areas includes different levels of injuries caused by lower temperatures in early spring. Because of the fact that the yield of maize was reduced due to chilling damage, the understanding of the physiological and biochemical mechanisms improving chilling tolerance of this species is very significant. Alleviating this growth suppression requires a further improvement of the maize chilling stress tolerance. There is no information about the physiological responses of the maize to Si under chilling stress, which may increase cold tolerance. In this work, we investigated photosynthetic and chlorophyll fluorescence parameters in chilling shocked maize plants, in order to determine the mechanisms of chilling tolerance and survival ability after chilling exposure.

\section{MATERIALS AND METHODS}

\subsection{Plant growth and treatments}

Seeds of maize (Zea mays'Fajr') were sown in top of the cylindrical plastic pots; four seeds were planted in each pot. Pots were $14 \mathrm{~cm}$ in diameter and $105 \mathrm{~cm}$ in depth, filled with $15 \mathrm{~kg}$ sandy loam soil ( $\mathrm{pH} 7.6, \mathrm{EC} 1.32 \mathrm{dS} \mathrm{m}^{-1}$, field capacity (FC) $23 \%$, organic carbon (OC) $1.09 \%$ ). After emergence, the seedlings were thinned to one plant per pot and irrigated every 5 days to maintain at $90 \%$ field capacity (FC). Plants were grown in a growth chamber located near the city of Miandoab, NW Iran $\left(46^{\circ} 6^{\prime} \mathrm{E}\right.$ and $\left.36^{\circ} 46^{\prime} \mathrm{N}\right)$ with day/night temperature of $25-28 \quad{ }^{\circ} \mathrm{C} / 17-19 \quad{ }^{\circ} \mathrm{C}$, relative humidity of $45-55 \%$ and daily photon flux density

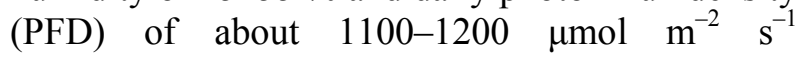
throughout the experimental period. Four weeks after sowing, half of the plants were sprayed with $10 \mathrm{mM} \mathrm{Si}$ (as potassium metasilicate, $\mathrm{pH}$ adjusted to 5.8). The volume of the spray was $400 \mathrm{ml}$ per pot. A drop of Tween $20(0.05 \%, \mathrm{v} / \mathrm{v})$ as surfactant was added to $500 \mathrm{ml}$ of the spray solutions. Control plants were sprayed with Tween 20 and equimolar concentrations of $\mathrm{KCl}$ for balancing $\mathrm{K}$ amounts. Ten days after the treatment, half of the control (untreated with $\mathrm{Si}$ ) and half of the Si-treated plants were placed to a controlled 
environment chamber under a $12 \mathrm{~h}\left(3 \pm 1^{\circ} \mathrm{C}\right)$ light (at $300 \mu \mathrm{mol} \mathrm{m} \mathrm{m}^{-2} \mathrm{~s}^{-1}$ photosynthetic photon flux $/ 12 \mathrm{~h}\left(2 \pm 1^{\circ} \mathrm{C}\right)$ dark cycle at $65 \%$ relative humidity for 2 days. After the chilling treatment, all plants were returned to normal conditions as described above, to allow leaves to recover from stress. Samples were taken 2, 48 and $96 \mathrm{~h}$ after recovery after cold treatment. Each measurement was done independently and experiments were repeated at least three times.

\subsection{Analysis of growth parameters}

Leaves and roots were harvested and washed with distilled water, blotted dry on filter paper and after determination of fresh mass (FM) they were dried for $48 \mathrm{~h}$ at $70{ }^{\circ} \mathrm{C}$ for determination of dry mass (DM). Relative water content (RWC) was measured and calculated according to Habibi and Hajiboland (2012). The percentage of necrotic area was determined by measuring separately green and necrotic leaf area according to Irigoyen et al. (1996).

\subsection{Measurements of chlorophyll fluorescence parameters}

Chlorophyll fluorescence parameters were recorded using a portable fluorometer (OSF1, ADC Bioscientific Ltd., UK) for both dark adapted and light adapted leaves. Leaves were acclimated to dark for $30 \mathrm{~min}$ using leaf clips before measurements were taken. Initial $\left(\mathrm{F}_{0}\right)$, maximum $\left(F_{m}\right)$, variable $\left(F_{v}=F_{m}-F_{0}\right)$ fluorescence as well as maximum quantum yield of PSII $\left(\mathrm{F}_{\mathrm{v}} / \mathrm{F}_{\mathrm{m}}\right)$ were recorded. Light adapted leaves were used for measurement of steady-state $\left(\mathrm{F}_{\mathrm{s}}\right)$ and maximum $\left(\mathrm{F}_{\mathrm{m}}^{\prime}\right)$ fluorescence. Calculations were made for $\mathrm{F}_{0}^{\prime}$ $\left(\mathrm{F}_{0}^{\prime}=\mathrm{F}_{0} /\left[\left(\mathrm{F}_{\mathrm{v}} / \mathrm{F}_{\mathrm{m}}\right)+\left(\mathrm{F}_{0} / \mathrm{F}_{\mathrm{m}}^{\prime}\right)\right]\right)$, photochemical quenching, $\mathrm{q}_{\mathrm{P}}\left[\left(\mathrm{F}_{\mathrm{m}}^{\prime}-\mathrm{F}_{\mathrm{s}}\right) /\left(\mathrm{F}_{\mathrm{m}}^{\prime}-\mathrm{F}_{0}^{\prime}\right)\right]$ and nonphotochemical quenching, NPQ $\left(F_{m}-F_{m}^{\prime}\right) / F_{m}^{\prime}$ (Krall and Edwards, 1992).

\subsection{Chlorophyll a fluorescence measurements}

Chlorophyll a fluorescence transients (OJIP transients) were measured with a Plant Efficiency Analyser (PEA, Hansatech Instruments Ltd., King's Lynn, Norfolk, PE 32 1JL, England) in dark-adapted (for at least $20 \mathrm{~min}$ ) leaves. The OJIP transients were induced by a red light (peak at 627 $\mathrm{nm}$ ) of $3500 \mu \mathrm{mol} \mathrm{m} \mathrm{m}^{-2} \mathrm{~s}^{-1}$ (sufficient excitation intensity to ensure closure of all PSII reaction centers to obtain a true fluorescence intensity of
Fm) provided by the PEA through an array of six light-emitting diodes.

\subsection{The JIP-test (The analysis of the fluorescence rise O-J-I-P)}

The JIP-test (Strasser and Strasser, 1995; Strasser et al., 2004) was used to analyse each OJIP transient. The following data from the original fluorescence measurements were used: maximal fluorescence intensity $\left(\mathrm{F}_{\mathrm{m}}\right)$; fluorescence intensity at $50 \mu \mathrm{s}$ (considered as $\mathrm{F}_{0}$ ); the specific energy fluxes (per reaction center) for absorption (ABS/RC), trapping $\left(\mathrm{TR}_{0} / \mathrm{RC}\right)$, dissipation at the level of the antenna chlorophylls $\left(\mathrm{DI}_{0} / \mathrm{RC}\right)$ and electron transport $\left(\mathrm{ET}_{0} / \mathrm{RC}\right)$; the flux ratios or yields, i.e. the maximum quantum yield of primary photochemistry $\left(\varphi_{\mathrm{Po}_{0}}=\mathrm{TR}_{0} / \mathrm{ABS}=\mathrm{F}_{\mathrm{v}} / \mathrm{F}_{\mathrm{m}}\right)$, the efficiency $\left(\psi_{0}=\mathrm{ET} 0 / \mathrm{TR}_{0}\right)$ with which a trapped exciton can move an electron into the electron transport chain further than $Q \mathrm{~A}$, the quantum yield of electron transport $\left(\varphi_{\mathrm{Eo}}=\mathrm{ET}_{0} / \mathrm{ABS}\right)$; the phenomenological energy fluxes (per excited cross-section of leaf, $\mathrm{CS}$ ) for absorption (ABS/CS), trapping $\left(\mathrm{TR}_{0} / \mathrm{CS}\right)$, dissipation $\left(\mathrm{DI}_{0} / \mathrm{CS}\right)$ and electron transport $\left(\mathrm{ET}_{0} / \mathrm{CS}\right)$. The fraction of active PSII reaction centeres per excited cross-section $(\mathrm{RC} / \mathrm{CS})$ is also determined. In addition to above parameters, a multi-parametric expression, the performance index $\left(\mathrm{PI}_{\mathrm{abs}}\right)$, is also calculated (Strasser et al., 2000). The $\mathrm{PI}_{\text {abs }}$ regards the three main steps that regulate photosynthetic activity by a PSII reaction centre (RC) complex, namely absorption of light energy (ABS), trapping of excitation energy (TR) and conversion of excitation energy to electron transport (ET).

\subsection{Determination of total chlorophyll, anthocyanin, Si content and total free amino acids}

Leaf concentration of total chlorophyll and carotenoid was determined after extraction of pigments in the cold acetone and allowing the samples to stand for $24 \mathrm{~h}$ in the dark at $4{ }^{\circ} \mathrm{C}$ (Lichtenthaler and Wellburn, 1985). Determination of anthocyanin contents was carried out using the method of Wagner (1979). To calculate the amount of anthocyanins, the extinction coefficient 33,000 $\mathrm{mol}^{-1} \mathrm{~cm}^{-1}$ was used and anthocyanin content were expressed as $\mu \mathrm{mol} \mathrm{\textrm {g } ^ { - 1 }}$ FM. Leaves were prepared for determination of Si (Jaiswal, 2004) using Inductively-Coupled Plasma-Atomic Emission 
Spectrometry (ICP-AES, INTEGRA XL2, GBC Australia). Content of total free $\alpha$-amino acids was assayed using ninhydrin colorimetric method. Glycine was used for production of standard curve (Hwang and Ederer, 1975). Soluble protein was estimated spectrophotometrically by the Bradford method (1976).

\subsection{Determination of antioxidants and malondialdehyde}

Lipid peroxidation was estimated from the amount of malondialdehyde (MDA) formed in a reaction mixture containing thiobarbituric acid according to methods described elsewhere (Habibi and Hajiboland, 2012). The level of glutathione (GSH) was determined according to Singh et al. (2006) with few modifications. Samples of $0.5 \mathrm{~g}$ were homogenized in $6 \% \mathrm{~m}$-phosphoric acid $(\mathrm{pH} 2.8)$ containing $1 \mathrm{mM}$ EDTA. Two solutions were then prepared. Solution A consisted of $110 \mathrm{mM}$ $\mathrm{Na}_{2} \mathrm{PO}_{4} .7 \mathrm{H}_{2} \mathrm{O}, 40 \mathrm{mM} \quad \mathrm{NaH}_{2} \mathrm{PO}_{4} \cdot \mathrm{H}_{2} \mathrm{O}, 15 \mathrm{mM}$ EDTA, $0.3 \mathrm{mM}$ 5, 5'-dithiobis (2-nitrobenzoic acid) and $0.4 \mathrm{ml} \mathrm{l}^{-1}$ BSA (final $\mathrm{pH} 7$ ). Solution B consisted of $1 \mathrm{mM}$ EDTA, $50 \mathrm{mM}$ imidazole, $0.2 \mathrm{ml} \mathrm{l}^{-1} \mathrm{BSA}$ and an equivalent of 1.5 units GR activity (Sigma). The absorbance at $412 \mathrm{~nm}$ was read after 2 min. The GSH concentration was determined from a standard curve by preparing solutions of $0.5-16 \mathrm{mM}$ GSH. Levels of AsA followed the procedure described by Singh et al. (2006) with few modifications. Briefly, fresh leaf sample of a known weight $(1 \mathrm{~g})$ was extracted with $10 \mathrm{ml}$ of $5 \%(\mathrm{v} / \mathrm{v}) m$-phosphoric acid and centrifuged at $12,000 \times \mathrm{g}$ for $15 \mathrm{~min}$. AsA was determined in a reaction mixture consisting of $0.2 \mathrm{ml}$ of supernatant, $0.5 \mathrm{ml}$ of $150 \mathrm{mM}$ phosphate buffer $(\mathrm{pH} 7.4$, containing $5 \mathrm{mM}$ EDTA) and $0.2 \mathrm{ml}$ of deionized water. Colour was developed in reaction mixtures with the addition of $0.4 \mathrm{ml}$ of $10 \%(\mathrm{w} / \mathrm{v})$ TCA, $0.4 \mathrm{ml}$ of $44 \%(\mathrm{v} / \mathrm{v})$ phosphoric acid, $0.4 \mathrm{ml}$ of $\alpha, \alpha$-dipyridyl in $70 \%$ (v/v) ethanol and $0.2 \mathrm{ml}$ of $3 \%(\mathrm{w} / \mathrm{v}) \mathrm{FeCl}_{3}$. The reaction mixtures were incubated at $40{ }^{\circ} \mathrm{C}$ for $40 \mathrm{~min}$ and quantified spectrophotometrically at $525 \mathrm{~nm}$. Ascorbate standards were between 1 and $50 \mathrm{mmol}$ ascorbate in $5 \%(\mathrm{v} / \mathrm{v}) m$-phosphoric acid.

\subsection{Statistical analysis}

Experiment was performed according to a factorial design on the basis of Completely Randomize Design (CRD) with 10 pots as 10 independent replications. Statistical analyses were carried out using Sigma Stat (3.5) with Fisher LSD test $(\mathrm{P}<0.05)$.

\section{RESULTS}

In the absence of chilling stress, Si had no effect on the growth of maize seedlings (Table 1). A significant loss of FM was observed in maize plants under cold stress, i.e., in $96 \mathrm{~h}$ after recovery. However, the decrease extent in the Si treatment was less than that in the non-Si treatment. Chilling stress caused significant reduction of RWC, although Si application ameliorated this effect and decreased significantly damaging effects of cold on RWC. Reduction of RWC under chilling stress was alleviated by $\mathrm{Si}$ application, accompanied by an increase in FM (Table 1). Chilling stress dramatically increased the necrotic leaf area, while $\mathrm{Si}$ supplementation significantly decreased it. As shown in Table 1, cold alone increased necrotic leaf area by $8.6 \%$ after treatment for $96 \mathrm{~h}$ recovery, but the increase was only $2.2 \%$ when $\mathrm{Si}$ was applied. Concentration of Chla and $b$ were significantly decreased when the plants were exposed to cold shock in comparison with the nonstressed plants. Si-supplied plants showed the higher anthocyanin and carotenoid concentration as compared with those without application of $\mathrm{Si}$ under chilling-stress conditions. The concentration of soluble sugars in the leaves was increased by chilling stress (Table 1). The concentration of starch decreased significantly after $96 \mathrm{~h}$ of chilling stress. No significant increase of starch was found by $\mathrm{Si}$ application under normal temperature. Under chilling-stress conditions, plants showed an increase in amino acid concentration in the leaves when treated with Si while this change for protein content was negligible. $\mathrm{Si}$ supplementation dramatically increased the leaf $\mathrm{Si}$ concentration, but the $\mathrm{Si}$ concentration was not affected by chilling stress during all treatment periods. 
Table 1: Effect of Si supplementation on the shoot fresh mass (SFM), shoot dry mass (SDM), relative water content (RWC), necrotic leaf area, and the concentration of chlorophyll $a$ and $b$, carotenoid, anthocyanin, soluble sugars, starch, total free $\alpha$-amino acids, protein and $\mathrm{Si}$ in maize plants grown with or without $\mathrm{Si}$ under chilling-stress conditions

\begin{tabular}{|c|c|c|c|c|}
\hline & \multicolumn{2}{|l|}{ Non-stressed } & \multicolumn{2}{|c|}{ Chilling-stressed } \\
\hline & $-\mathrm{Si}$ & $+\mathrm{Si}$ & $-\mathrm{Si}$ & $+\mathrm{Si}$ \\
\hline SFM $\left(g_{\text {p plant }}^{-1}\right)$ & $13.9 \pm 1.22^{\mathrm{a}}$ & $14.1 \pm 1.36^{\mathrm{a}}$ & $10.6 \pm 0.84^{\mathrm{c}}$ & $12.1 \pm 1.12^{b}$ \\
\hline SDM (g plant $\left.{ }^{-1}\right)$ & $2.87 \pm 0.36^{\mathrm{a}}$ & $2.94 \pm 0.44^{\mathrm{a}}$ & $2.43 \pm 0.47^{\mathrm{a}}$ & $2.66 \pm 0.83^{\mathrm{a}}$ \\
\hline RWC (\%) & $70 \pm 3.2^{\mathrm{a}}$ & $73 \pm 1.8^{a}$ & $57 \pm 3.0^{b}$ & $69 \pm 2.4^{\mathrm{a}}$ \\
\hline Necrotic leaf area $(\%)$ & $00.0 \pm 00.0^{\mathrm{c}}$ & $00.0 \pm 00.0^{\mathrm{c}}$ & $8.60 \pm 1.30^{\mathrm{a}}$ & $2.20 \pm 0.82^{b}$ \\
\hline Chl $a\left(\mathrm{mg} \mathrm{g}^{-1} \mathrm{FM}\right)$ & $4.10 \pm 0.72^{a}$ & $3.90 \pm 0.47^{\mathrm{a}}$ & $3.04 \pm 0.26^{b}$ & $2.97 \pm 0.32^{b}$ \\
\hline $\mathrm{Chl} b\left(\mathrm{mg} \mathrm{g}^{-1} \mathrm{FM}\right)$ & $1.78 \pm 0.32^{\mathrm{ab}}$ & $2.46 \pm 0.57^{\mathrm{a}}$ & $1.06 \pm 0.22^{b}$ & $1.18 \pm 0.39^{b}$ \\
\hline Carotenoid (mg g $\left.{ }^{-1} \mathrm{FM}\right)$ & $0.98 \pm 0.33^{b}$ & $1.16 \pm 0.87^{b}$ & $1.21 \pm 0.41^{b}$ & $2.35 \pm 0.72^{a}$ \\
\hline Anthocyanin $\left(\mu \mathrm{mol} \mathrm{g} \mathrm{g}^{-1} \mathrm{FM}\right)$ & $4.78 \pm 0.78^{b}$ & $5.46 \pm 0.57^{b}$ & $6.06 \pm 1.00^{b}$ & $7.98 \pm 1.07^{\mathrm{a}}$ \\
\hline Soluble sugars ( $\left.\mathrm{mg} \mathrm{g}^{-1} \mathrm{FM}\right)$ & $12.3 \pm 2.6^{\mathrm{c}}$ & $14.2 \pm 3.35^{\mathrm{bc}}$ & $18.0 \pm 2.65^{\mathrm{ab}}$ & $20.7 \pm 3.12^{a}$ \\
\hline $\operatorname{Starch}\left(\mathrm{mg} \mathrm{g}^{-1} \mathrm{FM}\right)$ & $164 \pm 17.6^{\mathrm{a}}$ & $172 \pm 19.6^{\mathrm{a}}$ & $121 \pm 15.6^{b}$ & $118 \pm 21.6^{b}$ \\
\hline Amino acids $\left(\mu \mathrm{mol} \mathrm{g} \mathrm{g}^{-1} \mathrm{FM}\right)$ & $3.45 \pm 0.65^{b c}$ & $3.02 \pm 1.04^{\mathrm{c}}$ & $5.00 \pm 0.89^{b}$ & $6.80 \pm 1.67^{\mathrm{a}}$ \\
\hline Protein $\left(\mathrm{mg} \mathrm{g}^{-1} \mathrm{FM}\right)$ & $10.7 \pm 2.11^{\mathrm{a}}$ & $11.4 \pm 2.01^{\mathrm{a}}$ & $7.22 \pm 1.27^{\mathrm{b}}$ & $8.98 \pm 1.99^{a b}$ \\
\hline Leaf Si (mg g $\left.{ }^{-1} \mathrm{DM}\right)$ & $0.79 \pm 0.22^{b}$ & $2.16 \pm 0.85^{\mathrm{a}}$ & $0.86 \pm 0.33^{b}$ & $2.48 \pm 0.52^{\mathrm{a}}$ \\
\hline
\end{tabular}

Samples were taken $96 \mathrm{~h}$ after recovery after cold treatment. Data of each row indicated by the same letters are not significantly different $(\mathrm{P}<0.05)$.

Data are the mean $\pm \operatorname{SD}(\mathrm{n}=10)$.

Si supplementation had no effect on leaf $F_{v} / F_{m}$ ratio under the normal condition, but it was decreased by cold treatment after $2 \mathrm{~h}$ recovery in the chilling-stressed leaves (Fig. 1a). However, Si quickly and significantly increased the $\mathrm{F}_{\mathrm{v}} / \mathrm{F}_{\mathrm{m}}$ ratio after 2, 46 and $96 \mathrm{~h}$ recovery after cold treatment. The photochemical quenching $\left(\mathrm{q}_{\mathrm{P}}\right)$ of non-Sisupplemented plants showed little change in response to chilling treatment, and $\mathrm{Si}$ - supplemented plants showed a marked increase after $2 \mathrm{~h}$ recovery. In contrast, the nonphotochemical quenching (NPQ) of the maize plants increased significantly after chilling, and the most marked increase in NPQ was occurred for Sisupplemented leaves during $2 \mathrm{~h}$ after chilling stress. During recovery, NPQ gradually reduced in the Si-supplemented leaves, but not in the non-Sitreated leaves. 


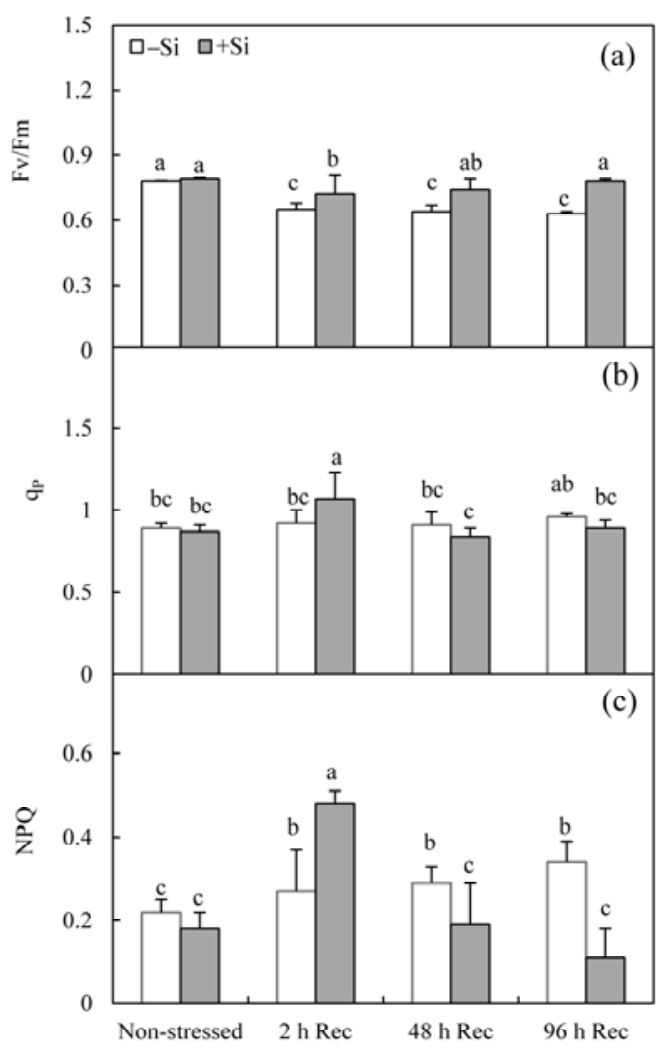

Figure 1: Changes in the maximum quantum yield of PSII $\left(\mathrm{F}_{\mathrm{v}} / \mathrm{F}_{\mathrm{m}}\right)(\mathrm{a})$, photochemical quenching $\left(\mathrm{q}_{\mathrm{P}}\right)(\mathrm{b})$ and nonphotochemical quenching (NPQ) (c) in maize plants grown with or without Si under chilling-stress conditions. Samples were taken 2, 46 and $96 \mathrm{~h}$ after recovery (Rec) after cold treatment. Symbols with error bars are the mean $\pm \mathrm{SD}(\mathrm{n}=10)$, and significant differences $(\mathrm{P}<0.05)$ are indicated by different letters.

To understand the precise effects of $\mathrm{Si}$ on the kinetics of recorded OJIP transients, data collected at water stress periods were analysed in Fig. 2. The effects of drought stress on the maximum quantum yield of primary photochemistry $\left(\mathrm{F}_{\mathrm{v}} / \mathrm{F}_{\mathrm{m}}\right)$ and the specific and phenomenological energy fluxes for light absorption, excitation energy trapping and electron transport are also showed in the form of a radar plot (Fig. 2). Chilling stress resulted in the deactivation of reaction centers (RC/CS) and decreased excitation energy trapping $\left(\mathrm{TR}_{0} / \mathrm{CS}\right)$ and electron transport $\left(\mathrm{ET}_{0} / \mathrm{CS}\right)$. Non-Si plants had performance indexes $\left(\mathrm{PI}_{\mathrm{abs}}\right)$ of 2-3, however, in Sisupplemented leaves, the $\mathrm{PI}_{\mathrm{abs}}$ values were respectively $200 \%$ higher than those recorded in non-Si-supplemented leaves (Fig. 2). Si- supplemented plants showed higher $\mathrm{PI}_{\text {abs }}$ with compared to those without application of Si under cold conditions.

Chilling-stressed plants displayed an increase in lipid peroxidation (Fig. 2) determined by the accumulation of MDA. However, the MDA level was decreased by foliar application of $\mathrm{Si}$ under chilling-stress conditions. Under chilling-stress conditions, plants were able to maintain higher GSH and AsA levels, as compared with nonstressed plants, but consistent with the decrease in lipid peroxidation seen in Si-supplied plants during stress, the levels of GSH showed an increment with a concomitant increase in AsA content (Fig. 2). 
Effect of foliar-applied silicon on photochemistry, ... and growth in maize plants subjected to chilling stress
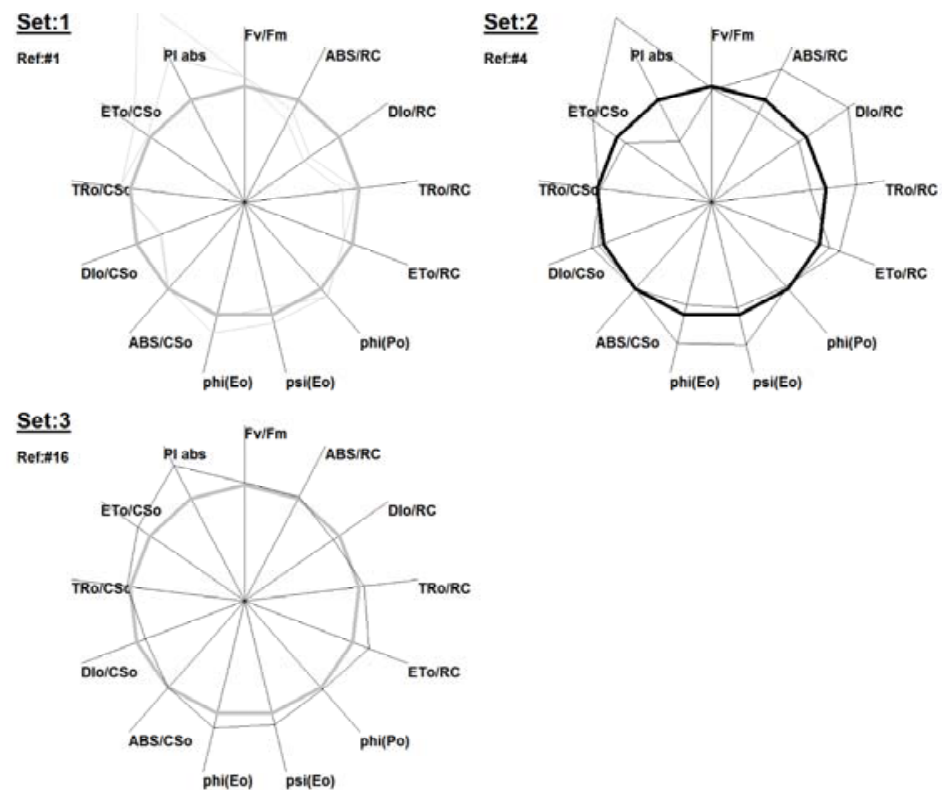

Key
Set 1: - Si plants (96 $\mathrm{h}$ after recovery after cold treatment)

Set 2: +Si plants (96 $\mathrm{h}$ after recovery after cold treatment)

Set 3: Averages

Figure 2: Radar plots depicting changes in the phenomenological (per CS) and specific (per RC) energy fluxes of absorption (ABS) excitation energy trapping (TR) and electron transport (ET). The changes in quantum efficiency $\left(\mathrm{F}_{\mathrm{v}} / \mathrm{F}_{\mathrm{m}}\right)$ and the performance indexes $\left(\mathrm{PI}_{\mathrm{abs}}\right)$ are also shown.

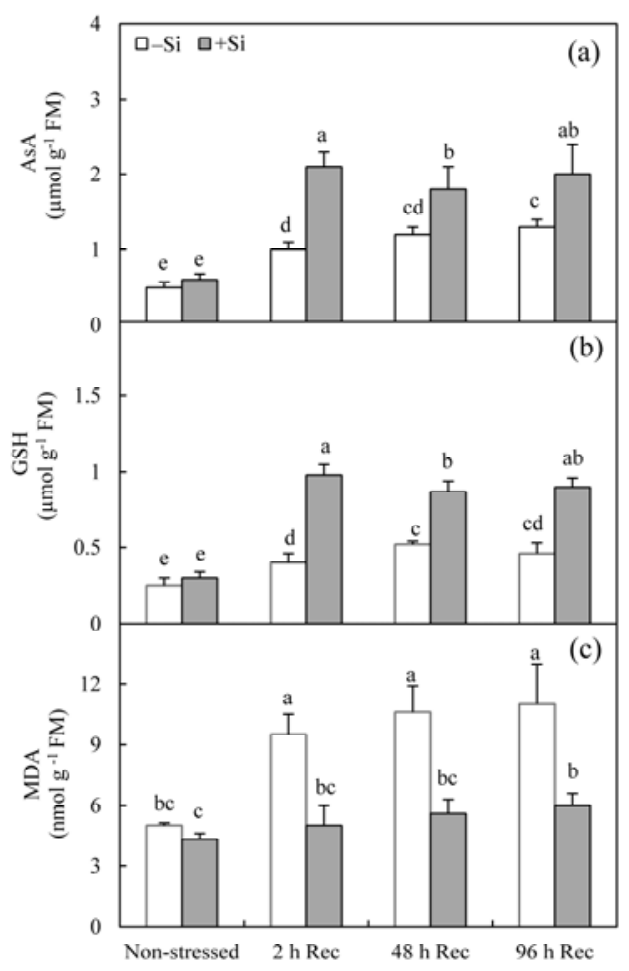

Figure 3: Changes in the concentrations of reduced ascorbate (AsA) (a) and glutathione (GSH) (b), and malondialdehyde (MDA) (c) in maize plants grown with or without Si under chilling-stress conditions. Samples were taken 2, 46 and $96 \mathrm{~h}$ after recovery (Rec) after cold treatment. Symbols with error bars are the mean $\pm \mathrm{SD}$ $(\mathrm{n}=10)$, and significant differences $(\mathrm{P}<0.05)$ are indicated by different letters. 


\section{DISCUSSION}

Our results showed that chilling-induced growth inhibition in maize seedlings was partly reversed by Si supplementation (Table 1). These results are in agreement with previous reports regarding the beneficial effects of $\mathrm{Si}$ on the growth and yield of Sorghum bicolor (L.) Moench under salt stress (Yin et al., 2013) and wheat cultivars under coldstress (Liang et al., 2008) conditions. Chillingsensitive plants exposed to low temperature often exhibit signs of water stress due to decreased root hydraulic conductance, leading to associated decreases in leaf water and turgor potential, followed by a reduction of growth (Waśkiewicz et al., 2014). We have already shown that the RWC in the non-Si-treated plants was significantly reduced under chilling stress. In this study, addition of Si helped the plants to maintain a high RWC, and dry matter production. The main mechanism for such roles of $\mathrm{Si}$ in maintaining higher water content in leaf tissues is hypothesized to be the reduced transpirational water loss via reduction of both cuticular and stomatal transpiration (Cooke and Leishman, 2011; Sonobe et al., 2011). Leaf necrosis is a typical external sign of chilling injury in chilling-sensitive plants. In this study, pre-Si treatment reduced the leaf necrosis under chilling stress conditions.

In the present study, though an expected enhancement in free amino acid level under chilling stress, Si application caused a significant stimulation in free amino acid level. Accumulation of these metabolites can function as osmolytes to preserve cell turgor and have the ability to protect membranes from stress damage (Krasensky and Jonak, 2012).

$\mathrm{F}_{\mathrm{v}} / \mathrm{F}_{\mathrm{m}}$ is an indication of overall photosynthetic capacity (Balouchi, 2010). Significant reduction of $\mathrm{F}_{\mathrm{v}} / \mathrm{F}_{\mathrm{m}}$ in chilling-stressed maize indicated that a proportion of PSII reaction centers is damaged or inactivated following photoinhibition, commonly observed in plants under stress (Baker and Rosenqvist, 2004). In the present study, there was a remarkable decrease in $F_{v} / F_{m}$ ratio of Si-treated leaves after chilling treatment and rapid increase during recovery, indicating that the capacity of electron transport was inhibited by chilling stress, and the damage in chlorophyll reaction center was reversible, but not in the non-Si-treated leaves.
Both Si and non-Si treatments showed a significant increase in NPQ just after cold shock, but then declined in Si-treated leaves during recovery, indicating that NPQ capacity of photosynthetic apparatus is changeable over different environments. It may be also suggested that the ability to cope with excess energy and photoinhibition was much improved in Si-treated plants. Based on the current results, it can be concluded that Si application not directly enhance chilling tolerance of maize plants, but it increased recovery ability from chilling injury. Plants have evolved a variety of protective mechanisms against the stress induced damage to cellular components, such as the dissipation of excess excitation energy and the synthesis of protective pigments, such as carotenoids and anthocyanins (Marczak et al., 2008; Huang et al., 2010). In this study, Si application caused a significant stimulation in these pigments under chilling stress. This finding is consistent with other published reports suggesting that the accumulation of carotenoids and anthocyanins is generally well correlated with chilling tolerance (Marczak et al., 2008).

The results presented that the decrease in the $\mathrm{PI}_{a b s}$ and down-regulation of photochemical activity during chilling stress conditions may be interpreted as evidence for PSII RC deactivation (Ivanov et al., 2006), and the $\mathrm{PI}_{\text {abs }}$ was much more sensitive than the $F_{v} / F_{m}$ ratio. These results indicated that PSII RC's are functionally altered by $\mathrm{Si}$ application through increase in density of active reaction centers, $\mathrm{RC} / \mathrm{CS}$.

The magnitude of oxidative damage is usually measured by MDA (an end product of membrane lipid peroxidation), as a marker for the ROSmediated cell membrane damage (Liu et al., 2009). In the present work, chilling stress caused membrane damage, as assessed by lipid peroxidation. However, $\mathrm{Si}$ could enhance antioxidant defense activity in maize plants under chilling stress, resulting in decreased membrane oxidative damage, and improved stability of cell membranes and enhanced stress tolerance. Fu et al. (2014) reported a consistent increase in reduced glutathione and ascorbate in Elymus nutans Griseb.in response to an increase in the intensity and duration of chilling stress. In agreement with 
the above, in our study, the contents of total GSH and AsA increased under chilling stress. GSH and AsA concentrations were higher in Si-treated plants under chilling stress compared with $-\mathrm{Si}$ ones. Our results suggest that improvement of maize tolerance to chilling stress by $\mathrm{Si}$ supplementation may be achieved by maintaining a relative high content of GSH and AsA as well as activation of antioxidant defense capacity in coldstressed plants.

In conclusion, results from this study showed that the foliar application of $\mathrm{Si}$ alleviated effects of chilling on plant growth. In the present study, there was a remarkable decrease in $\mathrm{F}_{\mathrm{v}} / \mathrm{F}_{\mathrm{m}}$ ratio of Si- treated leaves after cold treatment and rapid increase during recovery, indicating that the damage in chlorophyll reaction center was reversible, but not in the non-Si-treated leaves. This can be explained by enhancement of efficiency for dissipation of excess photon energy in the PSII antenna, determined as nonphotochemical quenching as well as accumulation of protective pigments, such as carotenoid and anthocyanin leading to the protection of PSII from photo-damage. Our results suggest that improvement of maize tolerance to chilling stress by Si supplementation is achieved by maintaining a relative high content of antioxidants and photochemical reactions.

\section{REFERENCES}

Battal, P., Erez, M.E., Turker, M., Berber, I. 2008. Molecular and physiological changes in maize (Zea mays) induced by exogenous NAA, ABA and MeJa during cold stress. Annales Botanici Fennici. 45: 173-185. DOI: $10.5735 / 085.045 .0302$

Bradford, M.M. 1967. A rapid and sensitive method for quantitation of microgram quantities of protein utilizing the principle of protein-dye binding. Anal. Biochem., 72: 248-254. DOI: 10.1016/00032697(76)90527-3

Broadley, M., Brown, P., Cakmak, I., Ma, J.F., Rengel, Z. and Zhao, F.P. 2011. Beneficial Elements. In: "Marschner's Mineral Nutrition of Higher Plants" (Ed.): Marschner, P.. UK, Academic Press, London. PP. 249-269.

Baker, N.R. and Rosenqvist, E. 2004. Applications of chlorophyll fluorescence can improve crop production strategies: an examination of future possibilities. J. Exp. Bot., 55: 1607-1621. DOI: 10.1093/jxb/erh196

Balouchi, H.R. 2010. Screening wheat parents of mapping population for heat and drought tolerance, detection of wheat genetic variation. Int. J. Biol. Life Sci., 6: 56-66.

Dallagnol, L.J., Rodrigues, F.A., Tanaka, F.A.O., Amorim, L. and Camargo, L.E.A. 2012. Effect of potassium silicate on epidemic components of powdery mildew on melon. Plant Pathol., 61: 323330. DOI: $10.1111 /$ j.1365-3059.2011.02518.x

Fu, J., Sun, Y., Chu, X., Xu, Y. and Hu, T. 2014. Exogenous 5-aminolevulenic acid promotes seed germination in Elymus nutans against oxidative damage induced by cold stress. PLoS One 9: e107152. DOI: 10.1371/journal.pone.0107152

Guntzer, F., Keller, C. and Meunier, J.D. 2011. Benefits of plant Si for crops: a review. Agron. Sustain. Dev., 32: 201-213. DOI: 10.1007/s13593-0110039-8

Habibi, G. and Hajiboland, R. 2013. Alleviation of drought stress by $\mathrm{Si}$ supplementation in maize (Pistacia vera L.) plants. Folia Hort., 25: 21-29.

Habibi, G. and Hajiboland, R. 2012. Comparison of photosynthesis and antioxidative protection in Sedum album and Sedum stoloniferum (Crassulaceae) under water stress. Photosynthetica, 50: 508-518. DOI: 10.1007/s11099-012-0066-y

Habibi, G. 2014a. Role of Trace Elements in Alleviating Environmental Sress. In: "Emerging Technologies and Management of Crop Stress Tolerance Biological Techniques" (Eds.): Ahmad, P. and Rasool, S. Elsevier, Boston, USA, PP. 313-331.

Habibi, G. 2014b. Silicon supplementation improves drought tolerance in canola plants. Russian J. Plant Physiol., 61: 784-791. DOI: $10.1134 / \mathrm{S} 1021443714060077$

Huang, H.Y., Zhang, Q., Zhao, L.P., Feng, J.N. and Peng, C.L. 2010. Does lutein play a key role in the protection of photosynthetic apparatus in Arabidopsis under severe oxidative stress? Pak. J. Bot., 42: 2765-2774.

Huber, S.C., Huber, J.L., Campbell, W.H. and Redinbaugh, M.G. 1992. Apparent dependence of the light activation of nitrate reductase and sucrose phosphate synthase activities in spinach leaves on protein synthesis. Plant Cell Physiol., 33: 639-646.

Acta agriculturae Slovenica, 107 - 1, marec 2016 
Hwang, M. and Ederer, G.M. 1975. Rapid hippurate hydrolysis method for presumptive identification of group B streptococci. J. Clin. Microbiol., 1: 114115.

Irigoyen, J.J., Juan, J.P.D. and Diaz, M.S. 1996. Drought enhances freezing tolerance in a freezingsensitive maize (Zea mays). New Phytol., 134: 5359. DOI: 10.1111/j.1469-8137.1996.tb01145.x

Ivanov, A.G., Sane, P.V., Krol, M., Gray, G.R., Balseris, A., Savitch, L.V., Oquist, G. and Hüner, N.P.A. 2006. Acclimation to temperature and irradiance modulates PSII charge recombination. FEBS Lett, 580: 2797-2802. DOI: 10.1016/j.febslet.2006.04.018

Jaiswal, P.C. 2004. Soil, Plant and Water Analysis, (Ed.): Kalyani Publishers, New Delhi.

Krall, J.P. and Edwards, G.E. 1992. Relationship between photosystem II activity and $\mathrm{CO}_{2}$ fixation in leaves. Physiol. Plant., 86: 180-187. DOI: 10.1111/j.1399-3054.1992.tb01328.x

Jiao-jing, L., Shao-hang, L., Pei-lei, X., Xiu-juan, W. and Ji-gang, B. 2009. Effects of exogenous Si on the activities of antioxidant enzymes and lipid peroxidation in freezing-stressed cucumber leaves. Agric. Sci. China, 8: 1075-1086. DOI: 10.1016/S1671-2927(08)60315-6

Krasensky, J. and Jonak, C. 2012. Drought, salt and temperature stress-induced metabolic rearrangements and regulatory networks. J. Exp. Bot., 63: 1593-1608. DOI: 10.1093/jxb/err460

Liang, Y., Zhuc, J., Li, Z., Chua, G., Dingc, Y., Zhangc, J. and Sun, W. 2008. Role of Si in enhancing resistance to freezing stress in two contrasting winter wheat cultivars. Environ. Exp. Bot., 64: 286-294. DOI: 10.1016/j.envexpbot.2008.06.005

Lichtenthaler, H.K. and Wellburn, A.R. 1985. Determination of total carotenoids and chlorophylls $\mathrm{a}$ and $\mathrm{b}$ of leaf in dfferent solvents. Biochem. Soc. Trans., 11: 591-592. DOI: 10.1042/bst0110591

Liu, J., Lin, S., Xu, P., Wang, X. and Bai, J. 2009. Effects of exogenous silicon on the activities of antioxidant enzymes and lipid peroxidation in chilling-stressed cucumber leaves. Agric. Sci. China, 8: 1075-1086. DOI: 10.1016/S16712927(08)60315-6

Liu, P., Yin, L., Deng, X., Wang, S., Tanaka, K. and Zhang, S. 2014. Aquaporin-mediated increase in root hydraulic conductance is involved in $\mathrm{Si}$ induced improved root water uptake under osmotic stress in Sorghum bicolor L. J. Exp. Bot., 65: 47474756. DOI: $10.1093 / \mathrm{jxb} / \mathrm{eru} 220$
Magné, C., Saladin, G., Clément, C. 2006. Transient effect of the herbicide flazasulfuron on carbohydrate physiology in Vitis vinifera. Chemosphere, 62: 650-657. DOI: 10.1016/j.chemosphere.2005.04.119

Marczak, L., Kachlicki, P., Kozniewski, P., Skirycz, A., Krajewski, P. and Stobiecki, M. 2008. Matrixassisted laser desorption/ionization time-of-flight mass spectrometry monitoring of anthocyanins in extracts from Arabidopsis thaliana leaves. Rapid Commun. Mass. Sp., 22: 3949-3956. DOI: $10.1002 / \mathrm{rcm} .3819$

Maxwell, K. and Johnson, G.N. 2000. Chlorophyll fluorescence - a practical guide. J. Exp. Bot., 51: 659-668. DOI: 10.1093/jexbot/51.345.659

Oxborough, K. 2004. Using Chlorophyll $a$ Fluorescence Imaging to Monitor Photosynthetic Performance. In: "Chlorophyll a Fluorescence, A Signature of Photosynthesis" (Ed.): Papageorgiou, G.C. Springer, Dordrecht, PP. 409-428. DOI: 10.1007/978-1-4020-3218-9_15

Saqib, M., Zörb, C. and Schubert, S. 2008. Si-mediated improvement in the salt resistance of wheat (Triticum aestivum) results from increased sodium exclusion and resistance to oxidative stress. Func. Plant Biol., 35: 633-639.

Singh, N., Ma, L.Q., Srivastava, M. and Rathinasabapathi, B. 2006. Metabolic adaptations to arsenic-induced oxidative stress in Pteris vittata L and Pteris ensiformis L. Plant Sci., 170: 274-282. DOI: 10.1016/j.plantsci.2005.08.013

Sonobe, K., Hattori, T., An, P., Tsuji, W., Eneji, A.E., Kobayashi, S., Kawamura, Y., Tanaka, K. and Inanaga, S. 2011. Effect of $\mathrm{Si}$ application on sorghum root responses to water stress. J. Plant Nutr., 34 : 71-82. DOI: $10.1080 / 01904167.2011 .531360$

Strasser, B.J., Strasser, R.J. 1995. Measuring fast fluorescence transients to address environmental questions: The JIP-test. In: Mathis, P. (Ed.), Photosynthesis: From Light to Biosphere, vol. V. Kluwer Academic Publishers, The Netherlands, pp. 977-980. DOI: 10.1007/978-94-009-0173-5 1142

Strasser, R.J., Srivastava, A., Tsimilli-Michael, M. 2000. The fluorescent transient as a tool to characterise and screen photosynthetic samples. In: Yunus, M., Pathre, U., Mohanty, P. (Eds.), Probing Photosynthesis: Mechanisms, Regulation and Adaptation. Taylor and Francis, London, pp. 445483.

Strasser, R.J., Tsimilli-Michael, M., Srivastava, A. 2004. Analysis of the chlorophyll $a$ fluorescence 
transient. In: Papageorgiou, G.C., Govindjee (Eds.), Chlorophyll a Fluorescence: A Signature of Photosynthesis. Springer, Dordrecht, pp. 321-362. DOI: $10.1007 / 978-1-4020-3218-9 \_12$

Suzuki, N., Koussevitzky, S., Mittler, R. and Miller, G. 2012. ROS and redox signalling in the response of plants to abiotic stress. Plant Cell Environ., 35: 259-270. DOI: 10.1111/j.1365-3040.2011.02336.x

Wagner, G.J. 1979. Content and vacuole/extra vacuole distribution of neutral sugars free amino acids, and anthocyanins in protoplast. Plant Physiol., 64: 8893. DOI: $10.1104 /$ pp.64.1.88

Waśkiewicz, A., Beszterda, M. and Goliński, P. 2014. Nonenzymatic Antioxidants in Plants. In: "Antioxidant Networks and Signaling Oxidative
Damage to Plants" (Eds.): Ahmad, P. Elsevier, USA, PP. 201-234. DOI: 10.1016/b978-0-12799963-0.00007-1

Yin, L., Wang, S., Li, J., Tanaka, K. and Oka, M. 2013. Application of $\mathrm{Si}$ improves salt tolerance through ameliorating osmotic and ionic stresses in the seedling of Sorghum bicolor. Acta Physiol. Plant., 35: 3099-3107. DOI: 10.1007/s11738-013-1343-5

Zhang, Q., Zhang, J.Z., Chow, W.S., Sun, L.L., Chen, J.W., Chen, Y.J. and Peng, C.L. 2011. The influence of low temperature on photosynthesis and antioxidant enzymes in sensitive banana and tolerant plantain (Musa sp.) cultivars. Photosynthetica, 49: 201-208. DOI: 10.1007/s11099-011-0012-4 